\title{
IN VIVO HEPATOPROTECTIVE EFFECT OF CAFFEIC ACID ON MERCURIC CHLORIDE-INDUCED BIOCHEMICAL CHANGES IN ALBINO WISTAR RATS
}

\author{
MANOGARAN MANJU, GANESAN JAGADEESAN* \\ Department of Zoology, Annamalai University, Annamalai Nagar, Chidambaram, Tamil Nadu, India. Email: jaga_zoo@yahoo.co.in
}

Received: 8 January 2019, Revised and Accepted: 19 February 2019

\begin{abstract}
Objective: Mercury (Hg) is a highly dangerous and also one of the harmful heavy metals which induces oxidative stress in the animal body. The present study is planned to examine the possible defensive result of caffeic acid (CA) against mercury chloride $\left(\mathrm{HgCl}_{2}\right)$-induced hepatotoxicity in male
\end{abstract} albino Wistar rats, Rattus norvegicus.

Methods: Sublethal dose of $\mathrm{HgCl}_{2}(1.29 \mathrm{mg} / \mathrm{kg}$ body weight) was administrated in rats for 15 days through oral dose and the CA was administrated for another 15 days on mercuric-intoxicated rats. After completing the scheduled exposure time, the rats were sacrificed and the whole liver organ was removed immediately from the animal, and it was used to carry out for biochemical and bioenzymological studies to observe.

Results: The level of lipid peroxidation (LPO) content reduced glutathione (GSH), superoxide dismutase (SOD), catalase (CAT), and glutathione peroxidase (GPx) in the liver tissue. CA is an energetic component in the phenolic propolis extract and also in a wide variety of plants, and a strong antioxidant helps to prevent oxidative damage and to reduce oxidative stress. The antioxidants such as GPx, CAT, and SOD and non-antioxidant GSH were significantly decreased, and also, the LPO level was increased in mercury toxicity rats. The treatment of CA (5 mg/kg body weight) in the liver tissue shows considerable declining in the level of oxidant content and along with an increase in the level of antioxidant properties by the way of improvement in liver tissues. Antioxidant and non-antioxidant enzyme (LOP, GSH, GPx, SOD, and CAT) activities were also significantly decreased to near untreated control level when compared to Hg-treated group. The CA acid alone treatment showed the enhanced antioxidant levels and not any alteration in the levels of biochemical parameters when compared with control.

Conclusion: These observations of the present experimental study clearly explained the detoxify effects and protective effect of $\mathrm{CA}_{\text {against }} \mathrm{HgCl}_{2}$ toxicity in liver tissue.

Keywords: Mercuric chloride, Hepatotoxicity, Caffeic acid, Lipid peroxidation, Superoxide dismutase, Catalase, Glutathione and glutathione peroxidase.

(C) 2019 The Authors. Published by Innovare Academic Sciences Pvt Ltd. This is an open access article under the CC BY license (http://creativecommons. org/licenses/by/4. 0/) DOI: http://dx.doi.org/10.22159/ajpcr.2019.v12i4.31609

\section{INTRODUCTION}

Mercury ( $\mathrm{Hg}$ ) and its compounds are called as worldwide pollutant because it easily distributed in air, water, and soil and possess high risk to global health. Nowadays, most of the researcher's attention has been refocused on the toxicity of the heavy metal which is present in various forms of mercury compounds. Mostly, inorganic forms of mercury compounds have used in the production of various products and agriculture medicines, etc. [1]. Normally, heavy metals are having high affinity with thiol groups $(-\mathrm{SH})$. If the sulfhydryl group is available at the enzyme active site, the heavy metals immediately react with it and decrease the availability of total sulfhydryl groups in cell to get oxidative stress [2,3]. Mercury $(\mathrm{Hg})$ and its compounds will bind to any free thiol available in the system, and the heavy metals are most frequently bound with the thiols due to its high concentrations [4]. Once the reaction rate was initiated, the stable mercury-sulfhydryl bond was formed because it is liable in the presence of other free total sulfhydryl groups [5]. Chen [6] have also suggested that mercury and its compounds are biochemically toxic as it binds to sulfhydryl groups $(-\mathrm{SH})$ and leads to disruption of protein structures and functions. In the present experimental study, the decreasing level of total protein content presents in the liver tissues of rats when treated with mercury toxicity also supporting the above findings. Proteins are common fundamental biomolecules to all living organisms, and they are responsible for most of the biocomplex functions that make life in a possible way. and proteins also act as major structural ingredients of living beings. Proteins play a vital role to carry out various types of physiological functions of an organism with the help of the enzymes or subunits of enzymes [7]. Naturally, formation of free radical process causes oxidative decoration of lipid leading to promote the production of lipid peroxidation (LPO) content and it also used as an indicator of oxidative stress. Promoting the imbalance between the production of reactive oxygen species (ROS) and free radicals (FR) in the organs due to the accumulation of LPO content caused the pathogenesis of different types of diseases, damages, and defects [8-10]. During the accumulation of LPO content such as aldehydes, inter alia, and malondialdehyde (MDA) leads to cellular membrane damages by oxidative destruction of polyunsaturated fatty acids $[11,12]$. Total amino acids are the building blocks of the protein in animal tissues. Most of the amino acids can easily interact with one another and with other molecules to form different complex molecules and also useful in the synthesis of cellular, subcellular, and other organic substances. The formations of different types of proteins mainly depend on the arrangement of amino acid sequences and in varying numbers. Different types of amino acid pool and their arrangement in the tissues may get vary in their chemical composition [13]. During the stressful condition, total free amino acids would also serve as energy precursor and also utilized for the synthesis of required proteins to overcome the stress. A number of experimental works have been conducted and explained the biological toxicity of $\mathrm{HgCl}_{2}$ in an organism by carrying out the biochemical fate of mercury toxicity [14]. Nowadays, an emerging interest has been focused on the use of phytochelating plant products with ameliorative potentials and its antioxidant activity in heavy metal intoxication therapy. Caffeic acid (CA) is one of the non-flavonoid catecholic compounds (the most common phenolic acids). It is easily available in several species of plants, and it also occurs in parts of fruits, vegetables, tea, coffee, and wine [15] and is regularly consumed in human diet [16,17]. In the past 
three decades, CA and its derivatives have a protective role that is clearly demonstrated by number of experimental works, showing that these chemicals have a variety of functions including acting as antioxidant and suppressing LPO [18-20]. It is a natural phenolic compound found in many plants. CA is a phenylpropanoid compound which is available in plant tissue metabolites [21]. This phenolic compound is mostly occurred in coffee, blueberries, apples, and ciders [22]. Sato [23] have reported that this compound is having high antioxidant property; due to this property, it is useful in neutralizing or nullifying the harmful effects of FR on cells. In the present experimental work, an increased level of protein content and simultaneously decreased level of total amino acid content were noticed in liver tissues of Hg-intoxicated rat when treated again with CA for another 15 days. This result suggested that the intoxicated cells of the respective organs are getting recovery from the toxicity effect of mercury compounds with the help of CA. An enhanced level of protein content in the examined tissues suggested that there is initiation of protein synthesis and simultaneously proteolytic conditions are stopped. The role of CA is mainly in protecting the cells from the adverse effect of $\mathrm{HgCl}_{2}$-induced toxicity.

\section{METHODS}

\section{Chemicals}

In the present experimental work, mercuric chloride $\left(\mathrm{HgCl}_{2}\right), \mathrm{CA}$, and all other necessary reagents of analytical grade were used and it was purchased from Hi-Media Laboratories Ltd., Mumbai, India.

\section{Animals}

Healthy male albino rats, Rattus norvegicus (180-200 g), were obtained from the Central Animal House, Department of Experimental Medicine, Raja Muthiah Medical College and Hospital Annamalai University, and maintained in an air condition room $\left(25 \pm 3^{\circ} \mathrm{C}\right)$ with a 12 -h light/12-h dark cycle. Feed, water, and ad libitum were provided to all the animals. The study protocols were approved by the Institutional Animal Ethics Committee of Rajah Muthiah Medical College and Hospital (Reg No: 160/1999/CPCSEA, proposal Number: 1156), Annamalai University, Annamalainagar.

\section{Experimental design}

A total of 24 animals were acclimatized in the animal cages for 15 days. The animals were randomized and divided into four groups, each group containing six rats. The toxic dosage of mercuric chloride has been obtained from our previous study as sufficient to elicit mild or moderate oxidative stress for mercuric chloride.

Group I: Untreated control - the animals were received standard diet and clean water ad labitum and observed for 15 days.

Group II: Mercury treatment - the animals were received $1.29 \mathrm{mg}$ of mercuric chloride/kg body weight orally every day up to 15 days.

Group III: Mercuric chloride followed CA treatment - the animals were received mercuric chloride followed by caffeic acid $(1.29 \mathrm{mg}$ $\mathrm{HgCl}_{2} / \mathrm{kg}$ body weight of animal for 15 days followed by caffeic acid $5 \mathrm{mg} / \mathrm{kg}$ body weight of animal 15 days administrated) treatment group.

Group IV: CA alone treatment - the animals were received CA ( $5 \mathrm{mg} / \mathrm{kg}$ body weight of animal for 15 days administrated) alone treated.

At the end of the experimental duration, rats were sacrificed by cervical dislocation. The whole liver tissues were isolated immediately from the animals and kept in an ice-cold saline and then used for the estimation of oxidant and antioxidant property studies.

\section{Estimation of LPO (TBARS)}

The concentration of LPO/TBARS in the selected tissues was determined by adopting the method of Nichens and Samuelson [24]. The known weight of selected organs (liver) was isolated from the animal in a cold room. The isolated organs were immediately homogenized in TrisHCL buffer ( $\mathrm{pH} 7.5$ ) for $5 \mathrm{~min}$. From the homogenized solution, $1 \mathrm{ml}$ of the organ (Liver) homogenate was taken in a clean dry test tube, and then, $2.0 \mathrm{ml}$ of TBA-TCA-HCL reagent was added to this content.
The contents were mixed thoroughly with lateral shaking of the test tubes. The mixture content was kept in an incubation chamber (boiling water bath $-60^{\circ} \mathrm{C}$ ) for $15 \mathrm{~min}$, and then, the organ mixture content was cooled with the help of running tap water. After cooling, the mixture was read the absorbance of the chromospheres at $535 \mathrm{~nm}$ against the reagent blank in an UV visible spectrophotometer (Spectronic-20, Bausch and Lamb). 1, 1', 3, 3'-tetramethoxypropane was used to construct the standard graph. The values were expressed as $n$ moles of MDA released/100 mg.

\section{Estimation reduced glutathione (GSH) activity}

The level of GSH in liver tissue was determined by the method of Beutler and Kelley [25]. The isolated organs (liver) were homogenized in $5 \mathrm{ml}$ of PBS buffer with the help of mortar and pestle. After completing the homogenization, the contents were centrifuged at $2500 \mathrm{rpm}$ for $5 \mathrm{~min}$. After completing the centrifugation, $2 \mathrm{ml}$ of clear supernatant was taken in a clean dry test tube and then mixed with $1.8 \mathrm{ml}$ of EDTA solution. To this content, $3.0 \mathrm{ml}$ of precipitating reagent was added and mixed thoroughly and then kept in the room temperature for $5 \mathrm{~min}$ before centrifugation. The mixed content was centrifuged at $3000 \mathrm{rpm}$ for $5 \mathrm{~min}$. After centrifugation, $2.0 \mathrm{ml}$ of the supernatant was taken in a clean test tube and then add the following reagents. $4.0 \mathrm{ml}$ of $0.3 \mathrm{M} \mathrm{Na}_{2} \mathrm{HPO}_{4}$ solutions and $1.0 \mathrm{ml}$ of DTNB reagent were added to the supernatant; the color developed was read at $412 \mathrm{~nm}$ in an UV spectrophotometer. A set of standard solutions containing 20-100 $\mathrm{g}$ of GSH was treated similarly. The values were expressed as $\mu \mathrm{g} / 100 \mathrm{mg}$ protein for tissues.

\section{Estimation of superoxide dismutase (SOD) activity}

SOD in the liver tissue was assayed by adopting the method of Kakkar et al. [26]. The known weight of selected organs (liver) was isolated from the animal immediately and then homogenized in $2 \mathrm{ml}$ of $0.25 \mathrm{M}$ sucrose solution and then centrifuged at 10,000 rpm for $30 \mathrm{~min}$ in cold condition. After completing the centrifugation, the supernatant was taken in a test tube and it was dialyzed with Tris-HCL buffer $(0.0025 \mathrm{M}$, pH 7.4) and it was used for enzyme assay. In a clean test tube, $1.2 \mathrm{ml}$ of dialyzed supernatant was taken and $1.2 \mathrm{ml}$ of $\mathrm{Na}_{4} \mathrm{P}_{2} \mathrm{O}_{7}$ buffer, $0.1 \mathrm{ml}$ of PMS, and $0.3 \mathrm{ml}$ of NBT reagents were added. The mixture contents were kept in a water bath at $30^{\circ} \mathrm{C}$ for $90 \mathrm{~s}$ for the purpose of incubation. After completing the incubation, the contents were made up to $3.0 \mathrm{ml}$ by adding glass distilled water, and then, $0.2 \mathrm{ml}$ of NADH reagents were added for initiating the reaction. The reaction was stopped by the addition of $1.0 \mathrm{ml}$ of glacial acetic acid and then added with $4.0 \mathrm{ml}$ of n-butanol. The reaction mixture was stirred vigorously and shaken well. The mixture was allowed to stand for $10 \mathrm{~min}$ and then centrifuged for $15 \mathrm{~min}$ at $3000 \mathrm{rpm}$. After centrifugation, the butanol layer was separated and the color intensity of the chromogen was measured at $560 \mathrm{~nm}$ in UV spectrophotometer against butanol as blank and the system devoid of enzyme served as control. One unit of enzyme activity is defined as the enzyme reaction which generates $50 \%$ inhibition of NBT reduction in $1 \mathrm{~min}$ under the assay condition and is expressed as specific activity in units/mg protein. The specific activity of the enzyme was expressed as unit/min/mg of protein for tissues.

\section{Estimation of catalase (CAT) activity}

The activity of CAT in the liver tissue was determined by the method of Sinha [27]. The isolated known weight selected organs (Liver) were homogenized in $2.0 \mathrm{ml}$ of PBS solution. After completing the homogenization, the contents were centrifuged for $10 \mathrm{~min}$ at $2000 \mathrm{rpm}$. After centrifugation, $0.1 \mathrm{ml}$ organ sample (tissue homogenate) was taken in a clean dry test tube and the $0.9 \mathrm{ml}$ of PBS and $0.4 \mathrm{ml}$ of $\mathrm{H}_{2} \mathrm{O}_{2}$ were added in contents and kept in room temperature for 30-60 s, and then, $2 \mathrm{ml}$ of dichromate acetic acid mixture was added in the contents and then kept in an incubation chamber at $37^{\circ} \mathrm{C}$ for $10 \mathrm{~min}$. After completing the incubation period, the contents were allowed to cool in the room temperature. The color developed was read at $620 \mathrm{~nm}$ in an UV spectrophotometer. $\mathrm{H}_{2} \mathrm{O}_{2}$ was used to construct the standard graph. The values are expressed as $\mu$ moles $\mathrm{H}_{2} \mathrm{O}_{2}$ consumed $/ \mathrm{min} / \mathrm{mg}$ protein. 


\section{Estimation of glutathione peroxidase (GPx) activity}

The activity of GPX in the liver tissue was measured by the method of Rotruck et al. [28]. The known weight of selected organs (liver) was homogenized in $2.0 \mathrm{ml}$ of PBS and then centrifuged at $2500 \mathrm{rpm}$ for 5 min. After completing the centrifugation, $0.2 \mathrm{ml}$ of clear supernatant was taken in a clean test tube, and then, the following enzyme mixture was added. The enzyme mixture contained $0.2 \mathrm{ml}$ of $0.4 \mathrm{mM}$ of EDTA and $0.1 \mathrm{ml}$ of $10 \mathrm{mM}$ of sodium azide. The reaction mixture was thoroughly mixed well and kept for $2 \mathrm{~min}$ at $37^{\circ} \mathrm{C}$ in an incubator. After completing the incubation period, $0.2 \mathrm{ml}$ of reduced GSH and $0.1 \mathrm{ml}$ of $\mathrm{H}_{2} \mathrm{O}_{2}$ were again added to the above mixture and then again incubated at $37^{\circ} \mathrm{C}$ exactly for $10 \mathrm{~min}$. The reaction was arrested by the addition of $0.5 \mathrm{ml}$ of $10 \%$ TCA. The color was developed and then read at $412 \mathrm{~nm}$ in an UV spectrophotometer. Reduced GSH was used to construct the standard graph. The values are expressed as $\mu$ moles of GSH utilized/ $\mathrm{min} / \mathrm{mg}$ protein tissues.

\section{Histology and histopathological study}

For the qualitative analysis of liver tissue histoarchitecture, the liver tissue sample was fixed in $10 \%$ buffered formaldehyde for $48 \mathrm{~h}$ and dehydrated by passing successfully in different concentrations of ethyl alcohol and cleaned in xylene and embedded in paraffin. Sections of tissue (5-6 $\mu \mathrm{m}$ think) were prepared using a rotary microtome and rehydrated and then stained with hematoxylin and eosin dye, which was mounted in DPX medium for microscopic observations.

\section{Statistical analysis}

Values are given as mean \pm SD. for six rats in each group. The data for various biochemical parameters were analyzed using analysis of t-test and the group means were compared by Duncan's multiple range test [29] Values were considered statistically significant when $p<0.05$ and the values sharing a common superscript did not differ significantly.

\section{RESULTS}

Table 1 indicates that the level of LPO was drastically increased in mercuric chloride intoxicated rat and simultaneously there was decreased in the level of total reduced GSH content in the liver tissue of the mercuric chloride intoxicated rat when compared with control animals. During the recovery period, CA treatment followed by mercuric chloride-intoxicated rat liver tissue, the restoration of LPO and GSH level was noticed near to normal level.

Table 2 shows that the antioxidant enzyme (SOD, CAT, and GPx) activities were significantly decreased $(p<0.05)$ in mercuric chlorideintoxicated rat liver tissue when compared to the control. During the recovery period, the treatment of CA reversed the activities of all these antioxidant enzymes toward $(\mathrm{p}<0.05)$ near control level [Fig. 1].

\section{Histological and histopathological study}

Histological and histopathological observations in the liver tissue of rats

In the present experimental work, the whole liver organ was isolated from the normal, untreated control rats. In normal condition, liver organ consists of numerous numbers of hepatic cells which were uniformly arranged. The hepatocyte is the cell, which is constructing the cell plates (liver plates) of the lobule. The histoarchitecture of the liver tissue consists of polygonal lobules, which contain an intralobular vein in the central and portal triad at the periphery. The classical, structural, and functional unit of the liver is the liver lobule. The shape of the liver lobule is cylindrical in nature with a venous channel. At the same time, and the central vein travels through its axis. The hepatic veins are surrounded by a connective tissue. The sinusoids are lined by phagocytic cells called Kupffer cells.

Under the influence of $\mathrm{HgCl}_{2}$ treatment, the intoxicated liver shows serious pathological modifications occurred in its cellular architecture when compared to the control group. Dissimilarity in the size and shape and the irregular arrangement of hepatocytes were also present. The hepatocyte cell boundaries were completely damaged in many areas and this also disintegrated completely, and this condition leads to the formation of multinucleated cells. The cytoplasm appears to be vacuolated and the cells are filled with pyknotic nuclei. The cell boundaries show rupture in many places. These changes are associated with the hypertrophy of hepatocytes.

Mercury-intoxicated rats were again dosed with CA; the liver tissue shows the regular arrangement of hepatocytes. There are no enlargement and puzzlement of the liver cords, and there was no focal necrosis in the liver. The disintegrated cell boundaries were restored in certain areas. Rat fed with CA alone, the histoarchitecture of liver organ shows a remarkable increase in the size, and the shape of the hepatocytes was uniformly arranged. The complete histoarchitecture of the liver is maintained as like that of control.

\section{DISCUSSION}

In animals, the defense mechanism of antioxidant enzymes might be enhanced due to the accumulation of ROS in cells [30]. Both types of non-enzymatic and enzymatic antioxidants provide very good defense
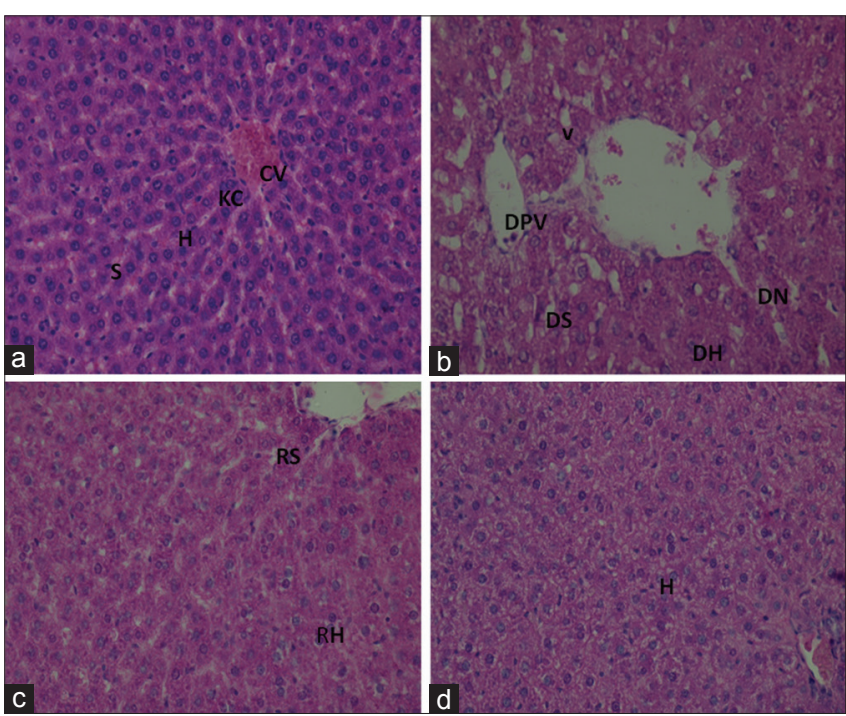

Fig. 1: Histology of experimental rat liver tissue in light microscope with hematoxylin and eosin staining at $\times 40$ magnification. (a) Control, (b) Mercuric chloride, (c) Mercury chloride followed by caffeic acid, (d) Caffeic acid

Table 1: The level of LPO and reduced GSH content of caffeic acid on mercuric chloride-intoxicated rat liver tissue

\begin{tabular}{lllr}
\hline Groups & Protein & Amino acid & LOP \\
\hline Control & $182.25 \pm 0.46$ & $352.13 \pm 1.42$ & $1.941 \pm 0.03$ \\
$\mathrm{HgCl}_{2}$ & $119.34 \pm 0.55$ & $467.18 \pm 0.86$ & $3.918 \pm 0.02$ \\
$\mathrm{HgCl}_{2}+$ Caffeic acid & $170.95 \pm 0.58$ & $412.55 \pm 0.92$ & $3.95 \pm 1.62$ \\
Caffeic acid & $195.33 \pm 1.02$ & $358.15 \pm 1.29$ & $54.03 \pm 0.03$ \\
\hline
\end{tabular}

(Values expressed as $\mu \mathrm{g} / \mathrm{g}$ wet weight of tissue) Each value is mean $\pm \mathrm{SD}$ for 6 rats in each group. The data for various biochemical parameters were analyzed using analysis of $\mathrm{t}$-test and the group means were compared by Duncan's multiple range test. Values were considered statistically significant at $\mathrm{P}<0.05$. LPO: Lipid peroxidation, GSH: Glutathione 
Table 2: The level of SOD, CAT, and GPx activity of caffeic acid on mercuric chloride-intoxicated rat liver tissue

\begin{tabular}{llll}
\hline Groups & SOD & CAT & GPx \\
\hline Control & $6.125 \pm 0.12$ & $70.38 \pm 3.23$ & $11.513 \pm 0.54$ \\
$\mathrm{HgCl}_{2}$ & $3.152 \pm 1.023$ & $38.59 \pm 2.52$ & $8.632 \pm 1.56$ \\
$\mathrm{HgCl}_{2}+$ Caffeic acid & $5.113 \pm 0.02$ & $60.36 \pm 2.28$ & $10.627 \pm 0.52$ \\
Caffeic acid & $6.682 \pm 0.058$ & $71.86 \pm 1.23$ & $12.037 \pm 0.24$ \\
\hline
\end{tabular}

(Values expressed as $\mu \mathrm{g} / \mathrm{g}$ wet weight of tissue) Each value is mean \pm SD for 6 rats in each group. The data for various biochemical parameters were analyzed using analysis of t-test and the group means was compared by Duncan's multiple range test. Values were considered statistically significant at $\mathrm{P}<0.05$. SOD: Superoxide dismutase, CAT: Catalase, GPx: Glutathione peroxidase

to the cells against ROS-induced cellular damages in the internal organs. This defense mechanism was mainly carried out by low molecular weight compounds (e.g., GSH) and antioxidant enzymes (e.g., SOD, CAT, and GSH -dependent antioxidant enzymes) [31]. GSH plays a vital role to neutralize ROS through the GSH-dependent antioxidant enzymes, and it acts as cofactor [32]. Promotion of antioxidant enzymes is one of the important factors of defense mechanism against oxidative stress in animals $[30,33]$. During the stress condition, the first line of defense mechanism consisting of the following antioxidant enzymes SOD, CAT, and GPx should be promoted against oxidative stress which converts superoxide FR into hydrogen peroxide and then into water and molecular oxygen [34]. ROS is a term that covers all types of elevated reactive, $\mathrm{O}_{2}$ holding molecules comprising FR. All are competent to react with membrane lipids, nucleic acids, proteins and enzymes, and other small molecules, causing the cellular damage. ROS is produced by a number of pathways [35]. Continuous synthesis of ROS promotes major alterations in subcellular structural molecules such as proteins and DNA, LPO of polyunsaturated fatty acids (PUFA), and changes of cellular antioxidant system. In tissue level, the measurement of MDA is an major indicator of LPO because it is the end product of LPO [36-38]. In the present experimental study, the CAT enzyme activity was found to be decreased because it plays a vital role to maintain the balance of the production of $\mathrm{H}_{2} \mathrm{O}_{2}$ and superoxide radicals. The declining in the level of SOD in the respective tissue also indicated that an enhanced level of superoxide radical production and consequently higher hydroxyl radical formation might be promoted. The continuous enhancement of hydroxyl radical also initiates the production of LPO content to rise in the internal organs. This is also confirmed in the current experimental work when the animals were treated with $\mathrm{Hg}$ poison. An enhanced level of LPO content and simultaneously decreased level of CAT enzyme activities were noticed in liver tissues of mercury-intoxicated rat as justified the above fact. A similar type of result was also observed in experimental animals by a number of research workers [39,40]. These experimental works have been reported that the exposure of $\mathrm{Hg}$ poison decreases the antioxidant systems and produces oxidative damages through $\mathrm{H}_{2} \mathrm{O}_{2}$ generation, thereby leading to enhancement of LPO content. Therefore, an increase in $\mathrm{LPO}$ by $\mathrm{HgCl}_{2}$ might provoke membrane biochemical and functional alterations that leads to the decrease in activities of SOD and CAT in liver tissues of $\mathrm{HgCl}_{2}$-treated rats that may be due to the slowdown of their process by the production of $\mathrm{H}_{2} \mathrm{O}_{2}$ because it is known that $\mathrm{H}_{2} \mathrm{O}_{2}$ involved in $\mathrm{Hg}$-induced cellular injury [41]. Manickam et al. also observed a similar type of result in $\mathrm{CCL}_{4}$-treated rats, and they recommend due to injury in liver damage. CAT and GPx are very important enzyme defense against dangerous reactive oxidizing molecules converted to $\mathrm{H}_{2} \mathrm{O}$, thereby providing protection to the cells from FR, and also GPx reduces the lipid hydroperoxide and $\mathrm{H}_{2} \mathrm{O}_{2}$ nontoxic product [42]. During the stressful condition, CAT enzyme plays an important role to reduce the $\mathrm{H}_{2} \mathrm{O}_{2}$ produced from the metabolism of long chain fatty acids in peroxisomes. However, the role of GPx is responsible to catalyze the reduction of both $\mathrm{H}_{2} \mathrm{O}_{2}$ and lipoperoxides. Due to this, it is considered as a one of the crucial defense antioxidant enzymes against LPO [43]. In all animal tissues, GPx is evenly distributed and it is also known as $\mathrm{H}_{2} \mathrm{O}_{2}$ degrading enzyme [44]. It is present in cytosol and mitochondrial matrix. GPx is one of the defense enzymes which scavenges harmful ROS. The main role of GPx enzyme is the removal and detoxification of hydrogen peroxide and lipid hydroperoxides in the presence of oxidized GSH [45-48]. During this reaction, the GSH is rapidly converted into oxidized glutathione (GSSG). In normal condition, the ratio of GSH/GSSG plays a vital role in adjusting the cellular redox status in animals. The disturbance occurred in the ratio of GSH/GSSG has promoting an impact on normal cellular functions [49]. Daniel et al. also observed comparable type of result in methotrexate-treated rats, they suggested that this is due to hepatotoxic damage. Reduction in cellular GSH, in turn, reduces the effectiveness of antioxidant defense of the liver against the increased ROS and thereby leads to hepatotoxicity [50]. In fact, GSH metabolism is one of the most essential anti-oxidative protection mechanisms in animals. During the recovery period, post-treatment of CA (mercuric chloride treatment followed by CA treatment), the decreased level of GSH content was significantly increased to reach near normal level in liver tissues of mercury-intoxicated rat. This result suggested that an administration of CA can promote the non-enzymatic antioxidant in the respective tissues leading to maintain adequate amount of GSH content in tissues. An enhanced level of GSH content has the function of protection that could provide the first line of defense against the influence of toxic heavy metals [39,51]. Moreover, an enhanced level of GSH content may be related to stop or control the oxidative challenge [52]. In the present experimental study, the decreased level of LPO content was noticed in liver tissues of mercury-intoxicated rats when treated with CA support our results. Deshmukh [53] have also been reported that the administration of CA reduces the oxidative stress in liver tissues of ICV-STZ-intoxicated rats. They suggested that the role of CA attenuates ICV-STZ-induced learning and memory deficit, cholinergic hypo-function, and oxidative-nutritive stress in rats. Yang et al. [54] have also examined the control of oxidative stress in vitro and in vivo condition by CA and RA combined treatment and estimated their potential in liver protection. CA also had a power of hepatic protection and also enhanced defensive effect of hepatocytes against t-BHP induced oxidative injure in rat liver cells. This could be attributed to the outstanding antioxidant properties (ability to scavenge FR) of CA. Soumya et al. [55] have also observed a similar type of result in liver tissues of mercury-intoxicated rat when treated with Aerva lanata plant extract. They observed that the decreased level of GSH was found in liver tissues due to intoxication with mercuric chloride. This reduced level of GSH content in the cells resulted from the depletion of GSH during oxidative injury of the hepatocytes [56]. During the administration of ethanolic extract of A. lanata on the hepatotoxic rats, the decreased level of GSH has been reverted back to normal due to an increased synthesis of GSH under the antioxidant effect of the extract [57]. They are suggested that an administration of A. lanata plant extract has possessing a high potential of several bioactive compounds which is responsible for promoting antioxidant properties in intoxicated animals.

\section{CONCLUSION}

CA can be used as an ameliorative agent against Hg toxicity-related disabilities in the future. Moreover, it saves the animals from $\mathrm{HgCl}_{2}-$ induced hepatotoxicity and carries out its transforming the biochemical and bioenzymological changes during the formation of free radical in animals. The present experimental work recommended that administration of CA can act as a preventive and protective effect of the animal from $\mathrm{HgCl}_{2}$ intoxication.

\section{AUTHORS' CONTRIBUTIONS}

The authors would like to express their thanks to the Professor and Head, Department of Zoology (UGC-SAP Sponsored), Annamalai University, for providing the infrastructure facility and support.

\section{CONFLICTS OF INTEREST}

The authors declare that they have no conflicts of interest. 


\section{REFERENCES}

1. Bharathi E, Jagadeesan G, Vijayakumar M. Hepato-ameliorative effect of hesperidin and ellagic acid on mercuric chloride intoxicated rats. Biomed Aging Pathol 2014;4:17-21.

2. Zalups RK. Molecular interactions with mercury in the kidney. Pharmacol Rev 2000;52:113-43.

3. Mahboob M, Mcneil L, Tolliver T, Ogden L. Effects of chromium picolinate on antioxidant enzyme levels in rats. Toxicol Sci 2002;154: 66-32.

4. Divine KK, Ayala-Fierro F, Barber DS, Carter DE. Glutathione, albumin, cysteine, and cys-gly effects on toxicity and accumulation of mercuric chloride in LLC-PK1 cells. J Toxicol Environ Health A 1999;57: 489-505.

5. Clarkson TW. The three modern faces of mercury. Environ Health Perspect 2002;110 Suppl 1:11-23.

6. Chen SY, Huang CY, Yokoi T, Tang CY, Huang SJ, Lee JJ, et al. Synthesis and catalytic activity of amino-functionalized SBA-15 materials with controllable channel lengths and amino loadings. J Mater Chem 2012;22:2233-43

7. Husveth F. Physiological and Reproductinal Aspects of Animal Production. Hungary: Debreceni Egyetem; 2011.

8. Bartosz G. Druga Twarz Tlenu. Wolne Rodniki w Przyrodzie, Wydawnictwo Naukowe Poland: PWN, Warszawa; 2004.

9. Niki E. Lipid peroxidation: Physiological levels and dual biological effects. Free Radic Biol Med 2009;47:469-84.

10. da Silva Fm, Marques A, Chaveiro A. Reactive oxygen species: A double-edged sword in reproduction. Open Vet Sci J 2010;4:127-33.

11. Esterbauer H, Waeg G, Puhl H, Dieber-Rotheneder M, Tatzber F. Inhibition of LDL oxidation by antioxidants. EXS 1992;62:145.

12. Cheeseman KH, Slater TF. An introduction to free radical biochemistry. Br Med Bull 1993;49:481.

13. Fleck CH, Kretzschel I, Sperschneider T, Apprenroth D. Renal amino acid transport in immature and adult rats during chromate and cisplatinum-induced nephrotoxicity. Amino Acid 2001;20:201-15.

14. Gutierrez LI, Mazzotti NG, Araujo AS, Klipel RB, Fernandes TR, Llesuy SF, et al. Peripheral markers of oxidative stress in chronic mercuric chloride intoxication. Braz J Med Biol Res 2006;39:767-72.

15. Clifford MN. Chlorogenic acids and other cinnamates nature, occurrence and dietary burden. J Sci Food Agric 1999;79:362-72.

16. Silva T, Oliveira C, Borges F. Caffeic acid derivatives, analogs and applications:Apatentreview(2009-2013). ExpertOpin Ther Pat2014;24: 1257-70

17. Jiang RW, Lau KM, Hon PM, Mak TC, Woo KS, Fung KP, et al. Chemistry and biological activities of caffeic acid derivatives from Salvia miltiorrhiza. Curr Med Chem 2005;12:237-46.

18. Parlakpinar H, Sahna E, Acet A, Mizrak B, Polat A. Protective effect of caffeic acid phenethyl ester (CAPE) on myocardial ischemiareperfusion-induced apoptotic cell death. Toxicology 2005;209:1-4.

19. Kitsati N, Fokas D, Ouzouni MD, Mantzaris MD, Barbouti A, Galaris D, et al. Lipophilic caffeic acid derivatives protect cells against $\mathrm{H} 2 \mathrm{O} 2$-induced DNA damage by chelating intracellular labile iron. J Agric Food Chem 2012;60:7873-9.

20. Du Q, Hao C, Gou J, Li X, Zou K, He X, et al. Protective effects of p-nitro caffeic acid phenethyl ester on acute myocardial ischemiareperfusion injury in rats. Exp Ther Med 2016;11:1433-40.

21. Clifford MN. Chlorogenic acids and other cinnamates nature, occurrence, dietary burden, absorption and metabolism. J Sci Food Agric 2000;80:1033-43.

22. Magnani C, Chiari BG, Isaac VL, Corrêa MA, Salgado HR. In vitro safety evaluation of caffeic acid. Athens J Health 2014b;1:1-8

23. Sato Y, Itagaki S, Kurokawa T, Ogura J, Kobayashi M, Hirano T, et al. In vitro and in vivo antioxidant properties of chlorogenic acid and caffeic acid. Int J Pharm 2011;403:136-8.

24. Niehaus WG Jr., Samuelsson B. Formation of malonaldehyde from phospholipid arachidonate during microsomal lipid peroxidation. Eur J Biochem 1968;6:126-30.

25. Beutler E, Kelley BM. The effect of disodium nitrate on RBC glutathione. Experintia 1963;29:97-101.

26. Kakkar P, Das B, Viswanathan PN. A modified spectrophotometric assay of superoxide dismutase. Indian J Biochem Biophys 1984;21:130-2.

27. Sinha AK. Colorimetric assay of catalase. Anal Biochem 1972;47: 389-94.

28. Rotruck JT, Pope AL, Ganther HE, Swanson AB, Hafeman DG, Hoekstra WG, et al. Selenium: Biochemical role as a component of glutathione peroxidase. Science 1973;179:588-90

29. Duncan BD. Duncan's multiple range tests for correlated and heteroscedastic mean. Biometrics 1957;13:359-64.

30. Velisek J, Stara A, Li ZH, Silovska S, Turek J. Comparison of the effects of four anaesthetics on blood biochemical profiles and oxidative stress biomarkers in rainbow trout. Aquaculture 2011;310:369-75.

31. Grim JM, Simonik EA, Semones MC, Kuhn DE, Crockett EL. The glutathione-dependent system of antioxidant defense is not modulated by temperature acclimation in muscle tissues from striped bass, Morone saxatilis. Comp Biochem Physiol A Mol Integr Physiol 2013;164:383-90.

32. Pacitti D, Wang T, Page MM, Martin SA, Sweetman J, Feldmann J, et al. Characterization of cytosolic glutathione peroxidase and phospholipidhydroperoxide glutathione peroxidase genes in rainbow trout (Oncorhynchus mykiss) and their modulation by in vitro selenium exposure. Aquat Toxicol 2013;130-131:97-111.

33. Jagadeesan G. Mercury poisoning and its antidotes. Biochem Cell Arch 2004; 4:5-60

34. Ural MŞ. Chlorpyrifos-induced changes in oxidant/antioxidant status and haematological parameters of Cyprinus carpio carpio: Ameliorative effect of lycopene. Chemosphere 2013;90:2059-64.

35. Krishnamurthy P, Wadhwani, A. Antioxidant Enzymes and Human Health. Antioxidant Enzyme. Rijeka, Croatia: InTech; 2012.

36. Uzun FG, Kalender Y. Chlorpyrifos induced hepatotoxic and hematologic changes in rats: The role of quercetin and catechin. Food Chem Toxicol 2013;55:549-56.

37. Kalender S, Uzun FG, Demir F, Uzunhisarcıklı M, AslanturkA. Mercuric chloride-induced testicular toxicity in rats and the protective role of sodium selenite and Vitamin E. Food Chem Toxicol 2013;55:456-62.

38. Apaydın FG, Baş H, Kalender S, Kalender Y. Subacute effects of low dose lead nitrate and mercury chloride exposure on kidney of rats. Environ Toxicol Pharmacol 2016;41:219-24.

39. Samipillai SS, Jagadeesan G. Protective effect of taurine and glutathione against mercury induced toxicity in the liver tissue of rats. Int J Mod Res Rev 2013;1:7-12.

40. Ibrahim AT. Effects of mercury chloride on oxidative stress biomarkers of some tissues of the African catfish Clarias gariepinus (Burchell, 1822). J Vet Sci Technol 2015;6:242.

41. Pillai SS, Jagadeesan G, Ramesh S, Arumugam P. Role of taurine and glutathione treatment on lipid peroxidation and antioxidant defense in mercury induced toxicity in rats. Int J Hum Sci and Tech 2010;1:72-81.

42. Manickam D, Ramamoorthy KP, Kumar MU, Kumar BS, Subramaniam S, Subramaniam S. Antioxidant activity of traditional siddha formulation of CCL4 induced liver fibrosis in rats. Int J Pharm Pharm Sci 2017:9:81-5.

43. Winston GW, Di Giulio RT. Prooxidant and antioxidant mechanisms in aquatic organisms. Aquat Toxicol 1991;19;137-61.

44. Venkatesan RS, Sadiq AM. In-vitro assay of effect of NaMSA on mercuric chloride induced oxidative stress in erythrocytes. Int J Curr Microbiol Appl Sci 2013;2:703-13.

45. Pappas AC, Zoidis E, Surai PF, Zervas G. Selenoproteins and maternal nutrition. Comp Biochem Physiol B Biochem Mol Biol 2008;151: 361-72.

46. Kanbur M, Eraslan G, Silici S. Antioxidant effect of propolis against exposure to propetamphos in rats. Ecotoxicol Environ Saf 2009;72: 909-15.

47. Vijayaprakash S, Langeswaran K, Kumar SG, Revathy R, Balasubramanian MP. Nephro-protective significance of kaempferol on mercuric chloride induced toxicity in wistar albino rats. Biomed Aging Pathol 2013;3:119-24

48. Celikoglu E, Aslanturk A, Kalender Y. Vitamin E and sodium selenite against mercuric chloride-induced lung toxicity in the rats. Braz Arch Biol Technol 2015;58:587-94.

49. Schafer FQ, Buettner GR. Redox environment of the cell as viewed through the redox state of the glutathione disulfide/glutathione couple. Free Radic Biol Med 2001;30:1191-212.

50. Daniel JA, Dal S, Jayan N, Devi SA. Protective activity of Asparagus racemosus in methotrexate-induced liver toxicity in wistar rats. Int $\mathrm{J}$ Pharm Pharm Sci 2018;11:253-6.

51. Rajkumar JS, Tennyson S. Mercury induced biochemical alterations as oxidative stress in Mugil cephalus in short term toxicity test. Curr World Environ 2013;8:55-9.

52. Dandapat J, Chainy GB, Rao KJ. Dietary Vitamin-E modulates antioxidant defence system in giant freshwater prawn, Macrobrachium rosenbergii. Comp Biochem Physiol C Toxicol Pharmacol 2000;127: 101-15.

53. Deshmukh R, Kaundal M, Bansal V, Samardeep H. Caffeic acid attenuates oxidative stress, learning and memory deficit in intracerebroventricular streptozotocin induced experimental dementia in rats. Biomed Pharmacother 2016;81:56-62. 
54. Yang SY, Hong CO, Lee GP, Kim CT, Lee KW. The hepatoprotection of caffeic acid and rosmarinic acid, major compounds of Perilla frutescens, against t-BHP-induced oxidative liver damage. Food Chem Toxicol 2013;55:92-9.

55. Soumya PS, Poornima K, Ravikumar G, Kalaiselvi M, Gomathi D, Uma C. Nephroprotective effect of Aerva lanata against Mercuric chloride induced renal injury in rats. J Pharm Res 2011;4:2474-6.
56. Tiejing LI, Zhang X, Zhao X. Powerful protective effects of gallic acid and tea polyphenols on human hepatocytes injury induced by hydrogen peroxide or carbon tetrachloride in vitro. J Med Plants Res 2010;4: 247-54.

57. Hanza AA. Curcuma longa, Glycyrrhiza glabra and Moringa oleifera ameliorate diclofenac-induced hepatotoxicity in rats. Am J Pharm Toxicol 2007;2:80-8. 